Cahsai, B. and E.C. Williamson. 1985. Erythrce: Un peuple en marche (XIXe et XXe siecle), L'Harmattan.

Debouvry, P. 1987. "Deplacement et installation des réfugiés angolais dans le sud du Zairre." In Le Developpement rural: Comprendre pour Agir. Paris: Orstom.

Economic and Social Research Council. 1982 Socio-Economic Survey of Spontaneously Settled Refugees in Port Sudan, Khartoum. Research Report 13.

Hansen, A. 1990. Refugee self-settlement versus settlement on government schemes. Washington: UNRISD Discussion Paper 17.

Harrell-Bond, B.E. 1986. Imposing Aid: Emergency Assistance to Refugees. Oxford: Oxford University Press.

ILO. 1983. Towards self-reliance: A programme of action for refugees in Eastern and Central Suidan. Report of the ILO. Geneva: UNHCR.

Karadawi, A. 1983. "Constraints on assistance to refugees: Some observations from the Sudan." World Development 11(6):537-547.

Kibreab, G. 1987. "Refugees and Development in Africa: The Case of Eritrea" Trenton: Red Sea Press

- 1989. "Local settlements in Africa: A Misconceived Option?" Journal of Refugee Studies 2(4):468-490.

- 1994. "Refugees in the Sudan: Unresolved Issues" in African Refugees: Development Aid and Repatriation, edited by $\mathrm{H}$. Adelman and J. Sorenson, Westview Press /York Lanes Press

Lassailly-Jacob, V. and Y. Gebresellasie. 1993. "La question des réfugiés en Afrique." Actes du Congrès de l'Entraide Missionnaire, Un Monde en Déplacement, Montréal.

Lassailly-Jacob, V. 1994. "GovernmentSponsored Agricultural Schemes for Involuntary Migrants in Africa: Some Key Obstacles to Their Economic Viability" in African Refugees: Development Aid and Repatriation, edited by $\mathrm{H}$. Adelman and J. Sorenson, Westview Press/York Lanes Press.

Marchal, R. 1989. "Le Soudan terre d'asile" in Le Soudan Contemporain, edited by M. Lavergne. Karthala: Cermoc.

Nelder, B.W. 1979. “Settlement of rural refugees in Africa" Disasters 3(4):393-402.

Nobel, P. 1982. Refugee Law in the Sudan. Research Report 64. Uppsala: Scandinavian Institute of African Studies.

Rogge, J.R. 1985. Too Many, Too Long: Sudan's Twenty Year Refugee Dilemma. New Jersey: Rowman \& Allenheld.

- 1987. "When Is Self-Sufficiency achieved? The Case of Rural Settlements in Sudan "In Refugees, $A$ Third World Dilemma, edited by J.R. Rogge. Rowman \& Littlefield.

Smock, D.R. 1982. "Eritrean Refugees in the Sudan." The Journal of Modern African Studies 20(3):451-465

Stein, B.N. and L. Clark. 1990. "Refugee integration and older refugee settlements in Africa." Paper presented at the 1990 meeting of the American Anthropological Association, New Orleans.

US Committee for Refugees. 1993. World Refugee Survey. Washington: USCR. $\square$

\title{
Repatriation of Sudanese Refugees from Ethiopia: A case study in manipulation of civilians during civil conflict
}

\author{
Alastair and Patta Scott-Villiers, and Cole P. Dodge
}

\section{Résumé}

Cet article retrace l'histoire du retour dramatique vers le Soudan de 150000 hommes, femmes et enfants depuis le camp de réfugiés d'Itang en Éthiopie. Ces gens ont été les grands sacrifiés de la guerre civile soudanaise, un statut que la communauté internationale a tardé à leur reconnaître et de ce fait à les aider comme tels. Cet article veut engager une discussion sur le rôle de la politique dans la protection des réfugiés et dans l'organisation de l'aide dans le contexte d'une guerre civile. L'information présentée ici provient à la fois d'une recherche sur le terrain effectuée pendant les trois mois du rapatriement et des rapports écrits sur cette période.

\section{Background}

Itang camp was established in June 1983 to cater to the needs of refugees fleeing Sudan's civil war that had then broken out. Itang was the largest camp established in Ethiopia for Sudanese refugees. Two additional camps were later opened at Panyido and Dima, south of Itang.

Although the government in Addis Ababa was secretive about Sudanese refugees, UNHCR was able to provide for their basic needs, albeit only after the international media had exposed appalling living conditions in these camps in 1986 (Woldridge 1987). Thus by 1988 , daily existence for the Sudanese refugees in Itang was reasonable, with not only a complete food basket provided to every family, but also adequate shelter, a functional health and education service, and clean drinking water. Despite the Ethiopian prohibition on refugees undertaking their own agriculture, the camp marketplace was active and underpinned the entire economy of neighbouring areas in Sudan. The area was reasonably secure and in many respects the camp became a Sudanese community within the borders of Ethiopia.

Alastair and Patta Scott-Villiers, and Cole $P$ Dodge have recently returned from their field work in Sudan.

\section{Itang: Relief and Political Strategy for the Sudan People's Liberation Army (SPLA)}

After the media exposure of suffering in the camp and the consequent increase in the provision of material support, Itang became the main route for relief to the southern Sudanese both in the camp and beyond. Up until 1989, the international community had ignored the suffering inside the rural areas of southern Sudan, but had been providing copiously to the refugee camps (over 75,000 tonnes of food to the three camps annually by 1990). The Ethiopian government ensured that the SPLA was able to run the camp without much international interference, and the camp administrators thus enjoyed more autonomy and far less international scrutiny than would normally be the case. It was widely accepted that the three camps were closely linked to SPLA military/political training and supply activities, and as such played a significant role inside both Ethiopia and Sudan.

In this process, the refugees who tried to escape the civil war became political pawns. A drought hit Upper Nile, Jonglei and Bahr el Ghazal provinces in 1987, which, in combination with a total breakdown of trade and commerce, created famine conditions. In mid-1988, an extraordinary number

Refuge, Vol. 14, No. 1 (April 1994) 
of destitute southerners trekked across the south of Sudan, guided on their way by the SPLA toward these Ethiopian camps. No stopping was allowed. In addition, between 1989 and 1991 relief workers for Operation Lifeline Sudan often witnessed the movement of truckloads of children, mostly young boys, travelling in the direction of Ethiopia for supposed education at the refugee camps. They were labelled "unaccompanied minors" and by the time of their return to Sudan in 1991 numbered over 14,000 .

\section{Population of Itang}

The number of refugees in Itang camp during its heyday was difficult to ascertain due to multiple registration and the failure to deduct figures of returnees (MDTMRR 1991). Additionally, local Nuer and Anuak people who populated the area around the camp and who were assisting their kin from across the border were also registered. In June 1991, chiefs of the Gajaak Nuer told us that they had been receiving food from the refugee camp even though some of them were over one week's walk from Itang itself, and inside Sudan. There was also a continuous flow of traders in and out of Itang, registering as refugees, receiving temporary relief and leaving again. UNHCR reported in July 1990 that 242,093 were claiming relief in Itang camp and 280,000 by January 1991 . The real number of refugees may never be known, but by mid-1991, when the camp population returned to Sudan, it was probably in the region of 150,000 according to UN and NGO sources.

\section{Itang as a Trading Centre}

As the number of refugees expanded, the camp at Itang became a centre for commercial activity. During the dry season the people of the Sobat and Pibor river basins and even from the Nile in southern Sudan came to Itang with their cattle for sale and bought significant quantities of grain and household items. They transported these back to Sudan by river. Small markets sprung up in Sudan where goods from Itang were sold. Relief sup- plies from Itang were dispersed over a wide geographical area. As a result of the war, the loss of the Arab merchant class (who had formed the backbone of the rural economy) led to -a distinct impoverishment of the population in southern Sudan (Dodge and Magne 1991). Itang was hit particularly hard because the civil war almost completely disrupted commerce between north and south, and between the large garrison towns in the south and the rural areas. The merchants that flourished at Itang, played a very important part in providing trade in SPLA areas and hence weakened the impact of the northern military strategy of isolating the southern civilian population and then blaming the SPLA for the scarcities and suffering.

The status of Itang was due in part to its position within the relatively well developed Ethiopian marketing network, but was also facilitated by the substantial relief inputs distributed to the refugees. UNHCR was able to attract significant donor support, but was prevented from administering this relief tightly, resulting in a food surplus which found its way into southern Sudan. Itang replaced the Arab trading class and was an important safety net for people economically affected by the war. Equally, the market at Itang was a major resupply source to the SPLA.

In interviews with chiefs after the abandonment of Itang camp, often a considerable distance from Itang (for example Abwong was approximately two weeks walk away), the loss of this marketplace was considered to be more significant than the arrival of large numbers of returnees.

Relief camps function as critical factors in the survival strategy of people under stress; families divide themselves, some remaining at home trying to produce food, others move to relief sites to collect assistance and still others move to and fro to trade. It was the role of the Ethiopian refugee camps as commercial and service centres that motivated the SPLA to attempt to recreate these camps inside Sudan. Their attempt was not particularly success- ful, because of the people's own social adaptation to the conditions of war and because they did not receive any significant donor or agency support.

Preparation for Movement as Conditions in Ethiopia Deteriorated

The disintegration of the Mengistu government accelerated in 1991, forcing the SPLA to think of alternative arrangements. Meetings with camp residents to discuss returning to $\mathrm{Su}$ dan were held by the SPLA in Itang as early as January 1991. Certain groups sent individual family members back to Sudan in advance of the dissolution of the camp (to the Akobo area for instance), where crops were planted by returnees weeks prior to the arrival of the rest of their families. This may have been standard practice in the light of the lack of agricultural possibilities at Itang, but nonetheless serves to illustrate the effective coping strategies employed.

The speed with which the Mengistu government collapsed was greater than anticipated by the SPLA, but it is significant that while the SPLA had contingency plans, neither the UN nor other agencies including the major donors had taken any preparatory action. Although the matter had been raised by various concerned NGOs, even UNHCR failed to respond, despite its mandate to protect and facilitate the repatriation of refugees. Even though repatriation to Sudan, which was still at war, was not considered desirable at the time, it must have been recognized as inevitable or at least highly likely in light of the political developments.

\section{The Demise of Itang: What Happened?}

On May 26, 1991, the refugees left Itang for Sudan en masse under SPLA guard after reported attacks on the camp. Itang camp, as described, vanished overnight. There are many conflicting stories regarding what happened, but it is apparent that the camp became a target in the downfall of the Mengistu regime. A major reason that the refugees felt unsafe and accepted SPLA 
safe passage back to Sudan, was that Mengistu had nurtured the SPLA. The refugees in Itang felt, rightly or wrongly, that they were identified with the SPLA and as such considered themselves vulnerable when the Ethiopian government fell. The refugees' acceptance of repatriation by the SPLA was also based on their knowledge that a relief structure now existed inside southern Sudan. Their faith in this relief structure may have been greater than warranted by reality.

The camp population crossed into Sudan at Jekau, where their movement was witnessed by a UN assessment team. Just as in 1988, the refugee movement was assisted by SPLA, who had fended off the depredations of bandits on the flooded route from the camp to the border and also on to Nasir. The SPLA left a unit at the camp as a rear guard which followed the stragglers back into Sudan.

\section{The Role of Operation Lifeline Sudan}

Operation Lifeline Sudan (OLS), a joint UNICEF/WFP/NGO relief operation under the loose coordination of UNDP functioning in parallel with ICRC, started in early 1989, and despite considerable political and physical constraints, managed to provide significant food and non-food relief and assisted in the re-establishment of networks of schools and health facilities in SPLA and government areas (Minear 1990). Although initially a consortium of UN agencies and allied NGOs working under a special agreement with the conflicting parties in Sudan, OLS was later to take its place as a program under the UN Department of Humanitarian Affairs, thereby becoming a UN operation similar to those in Yugoslavia, Angola, Mozambique and Cambodia.

The expansion of OLS coverage moved in the wake of expansion of SPLA territory and although never adequate, was instrumental in assisting the adaptive local coping mechanisms employed by the southern Sudanese toward recovery once conflict had moved away from their im- mediate homesteads. The main centres for relief in SPLA areas were inevitably in areas most accessible from Kenya and Uganda, but even the Ethiopian border areas including the Sobat and Pibor river basins deep inside southern Sudan benefitted from some relief under OLS.

However, in 1991, although the potential for a massive return of refugees from Ethiopia was very clear, OLS did not prepare adequately for the inevitable suffering of such a move. A proposal was made at an OLS program meeting in Kenya in October 1990 to supply Waat district and the Sobat basin with relief food, seeds, tools and fishing equipment by overland convoys to reduce the vulnerability of the local population. The proposal was accepted by all present, including UN representatives from Khartoum and a similar recommendation was made by the Multi-Donor Technical Mission in Ethiopia just a few months later. Regrettably, due to Sudanese government intransigence, little was put into place to reduce local vulnerability let alone assist returnees. Both refugee and OLS operations continued in isolation without taking into account the obvious political change in Ethiopia and its potential ramifications.

\section{Government of Sudan Limits Assistance to Civilians in SPLA \\ Areas}

WFP was the largest transporter of food in this area and had brought overland convoys up to Waat in late 1990. The WFP office in Khartoum, however, was refused permission from the government of Sudan for the movement of convoys into southern Sudan in the dry season of 1991 . UNICEF did deliver some seeds, tools and fishing equipment, but only after the embargo was lifted in late March, and in the absence of the complementary relief food this input was of more limited effect than intended. The failure of OLS at that time to extract the requisite permission from the government to allow adequate assistance in the Sobat/Waat area later conspired to increase the suffering of the returnees from Itang.
The government of Sudan's policy toward the relief of the people of southern Sudan at this time was described by USAID as "clearly capricious, if not blatantly obstructionist." The United Nations, although not completely unaware of the likely arrival of over 250,000 people from the three Ethiopian refugee camps $(150,000$ from Itang and 100,000 from Panyido and Dima), also did not protest. Perhaps they were tired from the endless strug. gle to negotiate each shipment of relief food with the conflicting parties. The United Nations accepted the suspension of the program until the rains began to fall and the area became virtually inaccessible to relief from the south.

\section{The Refugees Return}

On May 29, 1991 the authors witnessed the arrival of approximately 15,000 people at Jekau on the Ethiopia-Sudan border. These people were forced to continue moving by the bombing of Jekau by the Sudanese air force on that same day. Most proceeded to Nasir in Upper Nile province where some 130,000 were eventually registered during the next three weeks. A smaller group of twenty thousand refugees who originated from the Akobo area returned straight home. Interviews with those arriving at Jekau indicated a representative population drawn from every area of origin known to have been at Itang except for the Blue Nile group, who appeared later. This confirmed the report that all the residents of Itang camp had left.

The UN and NGOs had, from their small base at Nasir on the Sobat River, assisted the newcomers in setting up their camps. In Nasir the UN and local authorities established six registration sites where 130,000 returnees were registered during June 1991. A multiagency team including International Rescue Committee, World Vision International, Action International Contre Le Faim, Action Africa in Need, UNICEF and World Food Program, rapidly established food distribution, feeding centres, clinics and information dissemination systems. Due to the

Refuge, Vol. 14, No. 1 (April 1994) 
difficulties of moving in bulk supplies without permission from the government these facilities were in place for some time before the arrival of relief inputs such as food or shelter materials.

\section{Political Manipulation of the Returnees}

It was only with the arrival of 3,000 Uduk and Maban families, originally from Blue Nile, that it became clear that there was a significant element of SPLA control in the choices that at least some of the returnees were making. The Blue Nile group arrived at Nasir two weeks after the first returnees. They had walked to Maiwut, a location en route to their home territory, and had been turned around by the SPLA and brought to Nasir. By this time, many of the first wave of returnees had left Nasir in search of food, and the arrival of the second major wave allowed SPLA authorities to pressure the international community for continued assistance.

At Nasir they camped on a small hillock that projected above the flood plain by a few inches, very near to the UN base that had grown from the original small office in Nasir town. These Uduk and Maban people were denied permission to leave the camp by the SPLA until May 1992. They were the living (and dying) proof of the need for continued relief at Nasir. They were without kinship or other social links, without potential sources of local assistance and they were also caught between the SPLA-who suspected them of being allied to the governmentand the government-who suspected them of being allied to the SPLA. This refugee community from the Blue Nile was not native to the southern Sudan, but could not go back to their old homes due to persisting insecurity. While other ethnic groups were able to use their social linkages and ethnic identity to their advantage, this group was prevented from doing so and as a result was much more vulnerable.

The unaccompanied children were another group whose poor state was pointed out as a compelling reason for continued relief $(2,800$ arrived at $\mathrm{Nasir}$ from Itang; the majority had been at Dima and returned to Sudan via Pochalla). While it was true that significant relief was required, it is important to recognize the role the press played in focusing on the severely malnourished unaccompanied minors while ignoring the relatively healthy majority. Although this helped to generate what little assistance was offered, it was another example of how the returnees were manipulated. This interest in the children and the resulting speculation rapidly became a political issue and was a leading factor in the subsequent split in the leadership of the SPLA in July 1991.

\section{Some did not Believe that Itang had been Evacuated}

The local SPLA/SRRA authorities were well aware that without a highly visible humanitarian crisis the obstacles to relief, which included the objections of the government of Sudan, would be too great too allow any supplies to reach the area. Other objections to increased relief came from donors and others who initially did not believe that Itang camp had been evacuated nor that the registration figures provided by the United Nations were accurate. For example, for some weeks after the evacuation of Itang, U.S. government sources claimed that the refugees were still in Itang. As a result, the WFP office in Khartoum was initially unwilling to credit UN reports from the field. This delayed the organization of relief and also justified Khartoum's resistance to relief proposals. This was particularly galling to the field workers who, although not prepared in advance, managed to track the arrival of the returnees, established registration procedures, closely monitored the situation and provided accurate estimates of the numbers of returnees involved and the effectiveness of the relief effort.

\section{The Failure of the UN to Negotiate Adequate Relief for the Returnees}

By June 11, 1991 it was reported that nearly 100,000 returnees had been reg- istered in and around Nasir, of which about 40 percent were children, 40 percent women and 20 percent men. These figures were available to the UN team who negotiated a schedule of relief with Khartoum. However, the relief agreement which was announced on June 16 allowed for only 1,000 tonnes of grain and no other food commodities or non-food survival items such as blankets or shelter materials. Five hundred tonnes of grain were to be delivered by immediate airdrop and 500 tonnes by barge from the river port of Kosti in northern Sudan. Both the type and amount of food allowed was widely known to be inadequate-the diet was not balanced and provided for only a total of six kilos of whole wheat per person. There were limitations imposed on the number of days an airdrop could fly, so there was a long gap built into the agreement between the termination of the airdrop and the arrival of the barge from Kosti. Later in the year supplementary airdrops were negotiated but these were never enough to meet the needs and at no time was the food supply guaranteed. This created a chronic state of nutritional deficiency in those who had to remain in camps around Nasir.

The government of Sudan also failed to allow food to be delivered to other locations, where many of the returnees had settled or were heading. The concentration of the relief effort at Nasir meant that the dispersal of returnees to other areas was inevitably delayed, which ironically played into the hands of both the SPLA and the government in the north. The returnees became increasingly vulnerable and were more than ever pawns in a war they sought to escape.

The provision of shelter, blankets, seeds and tools was also inadequate, largely because of the restrictions placed on the mode of delivery. It was clear by mid July that a very large number of returnees would be staying in the Nasir and Sobat area during the remainder of the rains. In order to improve food security and thus reduce their dependence on relief food, it was necessary to provide seeds and tools in 
time for the second planting in late August. This deadline was not met; greatly jeopardizing those who had no kinship links with the local community.

Some donors agreed with the principle of limiting relief; arguing that the returnees could now go back to Itang, where it would be far easier to supply them (Brennan 1991). However this policy did not take into account the extremely poor security situation that prevailed in the Ethiopian border areas and which continues to this day, nor did it consider the SPLA tactic of keeping them in camps to attract relief.

\section{The ICRC Operation}

In contrast to the UN operation, the ICRC relief operation at Pochalla successfully assisted 100,000 returnees from Panyido camp. The ICRC obtained a far more comprehensive agreement from Khartoum than did the UN and had no need to convince donors of the need for assistance. Their relief flights were unrestricted and they used three planes for daily airdrops of grain, pulses [such as peas, beans or lentils], oil and salt, as well as supplementary foods for malnourished children, shelter material, medicines, blankets, cooking utensils, seeds and tools.

The scale of the ICRC operation highlights the inadequacies of the UN's overall performance and raises the question of why the UN did not also obtain a more satisfactory agreement for the returnees under its care. It should be pointed out, however, that there have been a number of instances in southern Sudan when ICRC have failed to gain access agreements while the UN have managed to do so. This demonstrates once again the degree of manipulation faced by those wishing to provide humanitarian relief in a situation of conflict.

\section{How the Returnees Fared}

Without doubt, the majority of the returnees who survived, did so due to their own coping mechanisms. From the time they arrived in Nasir until the first provision of relief food, five weeks had elapsed. Most people, on arrival in Nasir, were visibly exhausted from their journey and hungry. Many $(93,000)$ continued on while others waited or were forced to wait for relief at Nasir. Possessions brought from Itang such as clothes, blankets and cooking utensils were traded with the local people for food and those that were entitled, cashed in on kinship ties and received food from relatives. Even wild food in the surrounding area was eaten.

After waiting for the arrival of relief for as long as they could, many decided to move on to accessible home areas or, if their homes were inaccessible, at least to areas near their homes. The majority of those who remained in the Nasir area after a month were those who had local entitlements to both food and land for agriculture. These included Nuer of local origin and those from places such as Waat who had ties to local people by marriage. Some people, mainly the Shilluk from White Nile province, came when the relief airdrop started. In addition, some families from adjacent areas, notably Akobo, later sent some representatives into Nasir to reduce the food pressure in their home region whilst they cultivated. The flux of population stabilized by the end of June 1991 and a second registration was undertaken by the UN at the sites around Nasir.

The transition from a relatively easy life in the refugee camp to the hard realities of poor shelter, little food and unreliable relief cannot have been an easy one. However, to rural Sudanese who were refugees in Itang, not being able to produce food for their families was tantamount to losing control of their destinies, a state which had serious psychological consequences. Nearly everyone interviewed during the returnee registration process held the opinion that it was good to be home, or at least in Sudan. A visiting UNHCR officer in Nasir reported that despite the paucity of relief and difficulty of their circumstances, the returnees looked far happier in Sudan than when she had worked with them as refugees in Itang.
For those that had no claim to local resources and who had to remain in displaced camps around Nasir, the situation was desperate. This situation was well documented; suffice it to say that conditions were terrible, malnutrition the norm and deaths from diarrhoea very high.

During October 1991 among the Blue Nile displaced (the most vulnerable community at Nasir), morbidity and mortality were as follows (UN/OLS 1991):

$\begin{array}{lc}\text { Disease } & \text { Reported Deaths } \\ \text { Diarrhoea } & 75 \% \\ \text { Malaria } & 4 \% \\ \text { Respiratory infections } & 4 \% \\ \text { Approximate mortality rate from } \\ \text { Malaria: } 16 / 1000 / \text { month with } 45.8 \% \\ \text { of these deaths being children under } \\ \text { five years old. }\end{array}$

It is apparent that few of the returnees who moved through Nasir to their home areas returned to Nasir to reregister themselves and receive free food. In fact the question was often asked of returnees "Why have you not moved back to Nasir?" Invariably the answer given was "It is better to be with one's relatives and friends rather than waiting for food."

At the beginning of the returnee emergency operation, many believed that the provision of food and other relief in Nasir would attract people. This did not happen, instead requests were made through chiefs that returnees and local people alike should be assisted with tools, seeds and fishing equipment, health, education and cattle vaccination to help ensure food security and survival. It is a sad commentary that not enough of such support was provided to the returnees, particularly to those who returned to their own home areas.

Of the 150,000 people who fled Itang, approximately 120,000 moved on to home areas or cashed in on language affinity or kinship networks. These people benefitted only marginally from any relief; but they are now integrated into the life and community of southern Sudan, such as it is in a civil war. As far as is known, the great ma- 
jority have survived-despite the subsequent withdrawal of OLS from large areas of the south as a result of increased insecurity. It is known that their existence is very much on a knifeedge, vulnerable as they are to the vagaries of climate and disease, to the continuing destruction wreaked by the war and to the disruption of commerce. It seems likely that they have no capital left, only their tenacity to survive. Meanwhile they have weakened the economic capacity of their hosts to the point that any major change in their circumstances will cause yet another mass migration.

Of the other 30,000 , the greater proportion were the Blue Nile group. They were finally released from their role as hostages for relief and were allowed to move back toward their home territory in May 1992. However, with poor rains and a lack of any support from relief agencies (who were once again prohibited access) many floundered and subsequently half of them have been recorded as refugees in Ethiopia. The remainder have temporarily established themselves inside Sudan, in the Dagu/Chegile area, awaiting a late harvest. It would seem that the families have split-with dependants leaving in search of relief while other stronger family members continue to try to produce food. The success of their venture is, however, already compromised by both SPLA and government raids and the above mentioned denial of relief access.

One small success on the part of the international community was the return of some forty women and children, originally SPLA prisoners of war, to their homes in northern Sudan. Recognized by a UN worker in one of the camps, the ICRC negotiated their safe passage home. They were taken on a UN barge up the Nile to White Nile province where they were put under the protection of ICRC officials from Khartoum.

\section{Discussion}

This tale of forced movement, the struggle to survive and poor international response provokes some ques- tions and suggests some obvious conclusions. It is clear that the people who became refugees at Itang and subsequently returnees at Nasir were undermined by war, manipulated by the conflicting parties, and inadequately protected and assisted by the international community. Their survival had more to do with their own tenacity and coping strategies than any other external factor.

Were the political realities of their manipulation also useful to their own survival? Yes, without the interference of the SPLA many would never have reached Itang nor benefited from refugee security and the subsequent food, health and education programs they received there. Neither would they have managed to alert the international community so rapidly of their plight. On the other hand, perhaps many could have stayed with their families in their home areas-areas that subsequently saw the re-establishment of schools, health facilities and food security under OLS.

At issue is the unacceptable manipulation by the SPLA and government of Sudan (and the government of Ethiopia of the time) which the international community was powerless to prevent. The failure of the government of Sudan to allow the international agencies to provide for returnees' food and non-food needs once they returned to Sudan was completely unjustified. The limitation on the movement of the Blue Nile group at Nasir imposed by the SPLA was equally unjustified. Thus the second major issue is the failure of the international community to recognize the political aspects of the situation. As such, while managing effectively to support 150,000 people as refugees, they were unable to help them when they returned home. The UN in particular failed to recognize the vulnerability of the refugees to the changing politics of Ethiopia and was ill-prepared to protect them inside Ethiopia or to help them when they returned, despite a clear mandate of protection.

Should the international community have taken a stronger line? Would such interference have been helpful or merely added another conflicting party? It seems fair to conclude that yes, a stronger line should have been taken, on the basis of a thorough political understanding. However, the history of international humanitarian involvement in crossborder situations and conflict make it clear that it is not only a strong response that is needed, but also an intelligent, politically aware and coordinated one. Many have suggested that OLS, under the direct control of the Department of Humanitarian Affairs, would be more effective at dealing with such issues, but it has not succeeded so far in this respect.

We can conclude that, particularly in the context of war, the international community and particularly the UN with its mandate, needs to spend more time understanding the political factors at play in the suffering of civilians. Having recognized the forces involved, a consistent application of appropriate leverage should be brought to bear, based on the rights of civilians and especially children to humanitarian assistance. The $U N$ is in a unique position to demand these rights, to negotiate access and to publicize manipulation, particularly with its recently strengthened mandate for intervention, as applied in Yugoslavia, Angola and Cambodia.

Part of the negotiation for protection and assistance must include corridors of tranquillity from zones of displacement back to home territories. However it is crucial to recognize that such corridors include protection in, and access to, the home areas themselves and this protection and access must be continuous rather than occasional.

The third consideration is the importance of the local social, economic and cultural setting. This is a factor in survival that is often recognized, but seldom acted upon. The underlying rationale for assistance should be primarily that the beneficiaries are themselves responsible for their own survival. Relief inputs and programs must therefore reinforce this responsibility rather than undermine it. 
The fourth consideration is the degree of support provided to returnees or displaced persons by the international community compared to that provided to refugees. In 1987 it was estimated that per capita relief investment in the Sudanese refugees in Ethiopia was $\$ 30$, while at the same time aid to southern Sudanese displaced in Khartoum was of the order of $\$ 2.50$ per person (MDTMRR 1991). As the general level of security once more declines in southern Sudan, there is, yet again, movement of Sudanese into Ethiopia. We readily recognize that adequate assistance must be provided to them as refugees, nonetheless support to their home areas would go far to enhance the efforts of the southern Sudanese in improving their own food security and basic services, and making their homes a place where at least part of the family (if not all) can remain.

Is it necessary for people to live beyond their own borders just for the purposes of relief, basic services or trade? No, displaced persons, particularly those struggling to return to their homes and rebuild their self-reliance should be given the same level of support as refu- gees. The difficulties of providing such support are not so great as to warrant our ignoring the vital role that it plays. Conferring responsibility for survival means assisting in returnees' areas of origin, thereby eventually reducing the burden of support required. Such an approach also reduces the burden borne by traditional support networks. Without this, the stress of coping with the burden of dispossessed returnees is likely to result in greater levels of vulnerability and massive re-displacement among the home community.

Finally it is important to stress once again the issue of political manipulation. Between 1987 and 1988 it was estimated that 96 percent of fatalities in the southern Sudanese war were civilians. From our experience we can postulate that a large proportion of those civilians had been manipulated in some way or another into a state of extreme vulnerability which contributed to their deaths. It is this fact, more than any other, that should galvanize the international community toward an awareness of the politics of displacement and toward a more consistent approach to solidarity with and protection of the innocent victims of war.

\section{References}

Brennan T. 1991. Report to OFDA. Unpublished mimeograph.

Dodge, Cole P. and Raundalen Magne. 1991. Reaching children in war. Uppsala: Scandinavian Institute for African Studies.

Johnson, Douglas H. 1992. Increasing the trauma of return: An assessment of the UN's emergency response to the evacuation of the Sudanese refugee camps in Ethiopia in 1991. Unpublished mimeograph.

Minear, Larry. 1990. Humanitarianism under siege: A critical review of Operation Lifeline Sudan. Trenton, New Jersey: Red Sea Press.

Multi-Donor Technical Mission on Refugees and Returnees. 1991. Report on mission to western region Sudanese refugee camps. Unpublished mimeograph.

Scott-Villiers, A. and P. Scott-Villiers. 1991. The return of the Sudanese refugees from Itang camp, Cambela, Ethiopia. A report on their current situation, numbers, areas of origin and present location along the Baro, Pibor and Sobat Rivers of Southern Sudan. UN/ OLS, unpublished mimeograph.

UN/OLS. 1991. 1992 assessment and appeal. Unpublished mimeograph.

USAID. 1991. Southern Sudan assessment, Final report. Unpublished mimeograph.

Woldridge, Michael. 1987. "Why they fled," In War wounds, Development costs of conflict in Southern Sudan, edited by N. Twose and B. Pogrund. London: Panos. J

\section{Storm and Sanctuary: The Journey of Ethiopian and Eritrean Women Refugees By Helene Moussa, Ph.D. \\ Published by Artemis Enterprises, ISBN1-895247-08-x, $\$ 18.95$ plus}

"By building on the life histories of individual [women], Helene Moussa insightfilly unravels previously undocimented gender-related deprivations and difficulties suffered by women refugees in the period preceding and during flight. in first countries of asylum and in resettlement. Her perceptive study also shows the courage and determination with which these women maintain their identity and dignity... a valuable contribution to the understanding of the complex patriarchal social strictures which assign subordinate roles to women, as well as providing an innovative methodology which could be applied in studies of women refugees..." Dr. Gaim Kobreab, Author of Refugees and Development in Africa: The Case of Eritrea

Copies of this book are available from:

York Lanes Press, Suite 351, York Lanes, York University

4700 Keele Street, North York ON M3J 1 P3

Fax: (416) $736-5843 \cdot$ Tel: (416) $736-5843$
4. . careful attention to the intertwined categories of gender, race and class and the interacting forces of sexism and racism in policy and practice.. fills a glaring gap in current refugee studies:"

Ruth R. Dach Plerson,

Professor, Ontario Institule for Studies in Education.

"... a significant and unique contribution to our understanding of women refugees."

Geraldine Sadoway, Barrister and Solicitor, Toronto

Refuge, Vol. 14, No. 1 (April 1994) 